\title{
Sistem Manajemen Keselamatan dan Kesehatan Kerja Di Perseroan Terbatas Nilam Sari Cipta Amrizal
}

\author{
Syarifa Mahila, Nazifah, Upik Ema Emilia Susanti \\ Fakultas Hukum, Universitas Batanghari, Jambi \\ Correspondence email: mahila218@gmail.com; nazifahthojib@gmail.com; ema_lia75@yahoo.com
}

\begin{abstract}
Abstrak. Peseroan Terbatas Nilam Sari Cipta Amrizal, merupakan salah satu perusahaan yang bergerak dibidang Kontraktor Listrik yang berkedudukan di Jambi.Berdasarkan jenis kegiatan usahanya perusahaan ini memiliki risiko tinggi terhadap Keselamatan \& Kesehatan Kerja. Tujuan penelitian ini untuk mengetahui penerapan Sistem Manajemen Keselamatan dan Kesehatan Kerja di Perseroan Terbatas Nilam Sari Cipta Amrizal, kendala yang dihadapi dan upaya penyelesaiannya. Keselamatan dan kesehatan kerja merupakan salah satu hak pekerja yang harus dipenuhi sebagaimana diatur dalam Peraturan Pemerintah Nomor 50 Tahun 2012. Metode penelitian yang digunakan adalah tipe penelitian yuridis empiris dengan pendekatan analitik, dalam penelitian ini, penulis menggambarkan permasalahan yang diteliti,yang disusun berdasarkan teori dan konsep yang terkait untuk memperoleh gambaran secara menyeluruh dan sistematis mengenai sistem manajemen keselamatan dan kesehatan kerja. Sumber data dari penelitian lapangan dengan menggunakan metode wawancara dan penelitian kepustakaan. Data yang diperoleh dari penelitian lapangan maupun penelitian kepustakaan diolah menggunakan analisis kualitatif yaitu analisis data berdasarkan apa yang diperoleh dari lapangan maupun kepustakaan baik secara lisan maupun tertulis, disajikan dalam bentuk kalimat-kalimat yang logis.Adapun metode yang digunakan adalah metode berpikir induktif yaitu metode berpikir dari yang bersifat khusus kemudian ditarik pada satu kesimpulan yang bersifat umum.
\end{abstract}

Kata kunci: keselamatan, kesehatan, kerja.

Abstract. Limited Liability Company, Nilam Sari Cipta Amrizal, is a company engaged in the Electrical Contracting sector based in Jambi. Based on the type of business activity, this company has a high risk to Occupational Health \& Safety. The purpose of this study was to determine the application of the Occupational Safety and Health Management System in the Limited Liability Company of Nilam Sari Cipta Amrizal, the obstacles faced and the efforts to solve them. Occupational health and safety is one of the workers' rights that must be fulfilled as regulated in Government Regulation Number 50 Year 2012. The research method used is a juridical empirical research type with an analytical approach. In this study, the authors describe the problems under study, which are arranged based on theory and related concepts to obtain a comprehensive and systematic description of the occupational safety and health management system, data sources from field research using interview methods and literature research. Data obtained from field research and library research are processed using qualitative analysis, namely data analysis based on what is obtained from the field and literature both orally and in writing, presented in the form of logical sentences. The method used is the inductive thinking method, namely the method of thinking. from a specific nature then drawn to a general conclusion.

Keywords: safety, health, work.

\section{PENDAHULUAN}

Pekerja sebagai aset perusahaan sangat perlu mendapatkan perlindungan terutama perlindungan teknis yang berkaitan dengan Keselamatan dan Kesehatan Kerja terutama perusahaan yang tempat kerjanya berpotensi menimbulkan ancaman bahaya yang nantinya berpengaruh terhadap hubungan kerja antara perusahaan dengan pekerja. Untuk itu para pekerja sangat penting dibekali dengan perlindungan Keselamatan dan Kesehatan Kerja ( K3) oleh perusahaan. ${ }^{1}$

Penerapan Sistem Manajemen Keselamatan dan Kesehatan Kerja merupakan hal sangat penting karena bertujuan untuk mewujudkan kondisi lingkungan kerja yang baik, nyaman dan aman untuk menghindari atau meminimalisir kecelakaan kerja. Sistem Manajemen Keselamatan dan Kesehatan Kerja merupakan bagian dari sistem manajemen perusahaan secara keseluruhan dalam rangka pengendalian risiko yang berkaitan dengan kegiatan kerja guna terciptanya tempat kerja yang aman, efisien dan produktif. Dalam bekerja, seorang karyawan membutuhkan adanya jaminan atas keselamatan dan kesehatan kerja dari perusahaan. Hal ini merupakan suatu kebutuhan karena adanya jaminan terhadap keselamatan dan kesehatan kerja membuat pekerja merasa aman dan dengan sendirinya hasil pekerjaan atau kinerjanya akan lebih baik sehingga apa yang menjadi tujuan perusahaan maupun tujuan untuk tercapainya kesejahteraan pekerja dapat terpenuhi. Keselamatan dan Kesehatan Kerja sebagai standar untuk penilaian

${ }^{1}$ Gerry Silaban dan Salomo Perangin-angin, Hak Dan Atau Kewajiban Tenaga Kerja Dan Pengusaha/Pengurus Yang Ditetapkan Dalam Peraturan Perundangan Keselamatan Dan Kesehatan Kerja, (Medan: USU Press, 2008), hlm.1 
operasional perusahaan. Perusahaan yang tidak menerapkan K3 maka dapat dianggap tidak layak dan tidak menerapkan K3.

Selain perusahaan, pemerintah turut bertanggung jawab untuk melindungi kesehatan dan keselamatan kerja. Upaya yang dilakukan oleh pemerintah dengan mengeluarkan peraturan perundang-undangan yang mengatur tentang Keselamatan dan Kesehatan Kerja yaitu Undang-Undang No. 1 Tahun 1970 Tentang Keselamatan Kerja, sebagaimana yang diatur dalam pasal 2 , menjelaskan bahwa : "Keselamatan kerja dalam segala tempat kerja, baik di darat, di dalam tanah, di permukaan air di dalam air maupun di udara, yang berada di dalam wilayah kekuasaan hukum Republik Indonesia".

Demi terselenggaranya keselamatan dan kesehatan kerja perusahaan wajib menerapkan sistem manajemen keselamatan dan kesehatan kerja yang terintegrasi dengan manajemen perusahaan sebagaimana diatur dalam pasal 87 ayat 1 Undang - Undang Nomor 13 Tahun 2003 Tentang Ketenagakerjaan yang menyatakan bahwa: "Setiap perusahaan wajib menerapkan sistem manajemen keselamatan dan kesehatan kerja yang terintegritas dengan sistem manajemen perusahaan."

Sistem Manajemen Keselamatan Kerja diatur lebih lanjut dalam Peraturan Pemerintah No. 50 Tahun 2012 Tentang Penerapan Sistem Manajemen Keselamatan dan Kesehatan Kerja. Pengertian Keselamatan dan Kesehatan Kerja yang selanjutnya disingkat K3 sebagaimana dirumuskan pada Pasal 1 angka 2 adalah "segala kegiatan untuk menjamin dan melindungi keselamatan dan kesehatan tenaga kerja melalui upaya pencegahan kecelakaan kerja dan penyakit akibat kerja." Peraturan Pemerintah No. 50 Tahun 2012 tentang Penerapan SMK3 dijelaskan pula bahwa SMK3 adalah bagian dari sistem manajemen perusahaan secara keseluruhan dalam rangka pengendalian risiko yang berkaitan dengan kegiatan kerja guna terciptanya manajemen perusahaan yang teratur dan saling berhu bungan untuk mencapai tujuan produktivitas perusahaan yang telah ditetapkan terkait dengan K3. Tujuan Penerapan Sistem Manajemen Keselamatan dan Kesehatan Kerja diantaranya adalah mempekerjakan tenaga kerja sesuai dengan harkat dan martabatnya sebagai manusia, meningkatkan komitmen pimpinan perusahaan dalam melindungi pekerja, meningkatkan efisien dan produktivitas kerja untuk menghadapi kompetisi perdagangan global. Dengan demikian peraturan keselamatan kerja merupakan suatu usaha untuk melindungi pekerja dari bahaya yang timbul karena pekerjaan dan menciptakan kondisi yang aman bagi pekerja.

Keselamatan kerja (Occupational Safety) secara filosofi diartikan sebagai suatu pemikiran dan upaya untuk menjamin keutuhan dan kesempurnaan baik jasmani maupun rohani manusia khususnya pekerja. Keselamatan kerja erat kaitannya dengan mesin-mesin, alat kerja, bahan dan proses pengolahannya, landasan tempat kerja dan lingkungan serta cara-cara melakukan pekerjaan di perusahaan yang kemungkinan besar dapat menimbulkan kecelakaan kerja. Kecelakaan kerja yang dimaksud adalah suatu kejadian atau peristiwa yang tidak diinginkan yang merugikan manusia atau dalam hal ini pekerja dan dapat merusak harta benda. ${ }^{2}$

Keselamatan Kerja adalah keselamatan yang bertalian dengan mesin, pesawat alat kerja, bahan dan proses pengolahannya, landasan tempat kerja dan lingkungannya serta cara-cara melakukan pekerjaan baik dilingkungan darat, dalam dan permukaan air dan udara. Sedangkan Kesehatan Kerja adalah merupakan bagian dari ilmu kesehatan yang bertujuan agar tenaga kerja memperoleh keadaan kesehatan yang sempurna, baik fisik, mental maupun sosial sehingga memungkinkan tenaga kerja dapat bekerja secara optimal. ${ }^{3}$ Semua orang yang mempekerjakan orang lain wajib melaksanakan ketentuan-ketentuan ketenagakerjaan. Ketentuan-ketentuan tersebut menyangkut hak-hak lain pekerja selama hubungan kerja berlangsung sampai dengan berakhirnya hubungan kerja, yang sudah tercantum dalam Undang-Undang No. 13 Tahun 2003 tentang Ketenagakerjaan pasal 50 sampai dengan 63 menyatakan bahwa : "Hubungan kerja terjadi karena adannya perjanjian kerja antara pengusaha dan pekerja/buruh."

Ketentuan mengenai penerapan SMK3 diatur juga secara lebih rinci dalam Permenaker RI No. 05/ MEN/1996 tentang sistem manajemen K3. Pada pasal 3 (1) dan (2) dinyatakan bahwa setiap perusahaan yang mempekerjakan tenaga kerja sebanyak 100 orang atau lebih dan atau mengandung potensi bahaya yang ditimbulkan oleh karakteristik proses atau bahan produksi yang dapat mengakibatkan kecelakaan kerja seperti peledakan, kebakaran, pencemaran lingkungan dan Penyakit Akibat Kerja wajib menerapkan SMK3.

Perseroan Terbatas Nilam Sari Cipta Amrizal, merupakan salah satu perusahaan yang bergerak dibidang Kontraktor Listrik yang berkedudukan di Jambi. Perusahaan ini memiliki 42 (empat puluh dua) orang pekerja / karyawan yang terdiri dari 26 (dua puluh enam) orang karyawan tetap yang terdiri dari 14 (empat belas orang) ditempatkan sebagai pelaksana pekerjaan lapangan dan 10 (sepuluh) orang sebagai bagian pelaksana di gudang dan 2 (dua) orang sebagai tenaga administrasi, dan 16 (enam belas) orang sebagai karyawan tidak tetap yang ditempatkan pada pekerjaan dilapangan. Walaupun pekerja pada Perseroan Terbatas Nilam Sari Cipta Amrizal ini berjumlah 42 (

${ }^{2}$ Erni Darmayanti, "Perlindungan Hukum Terhadap Pelaksanaan Keselamatan Dan Kesehatan Kerja (K3) Pada Perusahaan", Jurnal Cendikia Hukum, Vol.3 No.2, (Maret 2018): 286.

${ }^{3}$ Abdul Hakim Hasibuan, Dasar-Dasar Hukum Ketenagakerjaan Indonesia, (Bandung: PT.Citra Aditya Bakti, 2014), hlm.109. 
empat puluh dua ) orang, belum mencapai seratus orang tetapi berdasarkan jenis kegiatan usahanya memiliki risiko tinggi terhadap Keselamatan dan Kesehatan Kerja. Dengan demikian perusahaan ini wajib menerapkan Sistem Manajemen K3. Permasalahanya adalah apakah pelaksanaan perlindungan Keselamatan dan Kesehatan Kerja terhadap pekerja di Perseroan Terbatas Nilam Sari Cipta Amrizal sudah sesuai dengan peraturan perundang-undangan mengingat perusahaan ini memiliki potensi resiko bahaya kecelakaan kerja. Selain itu sudahkah perusahaan ini menerapkan Sistem Manajemen Keselamatan dan Kesehatan Kerja yang merupakan salah satu hak pekerja yang harus dipenuhi sebagaimana diatur dalam Peraturan Pemerintah Nomor 50 Tahun 2012 Tentang Penerapan Sistem Manajemen Keselamatan dan Kesehatan Kerja.

Perlindungan tenaga kerja meliputi aspek-aspek yang cukup luas, yaitu perlindungan keselamatan, kesehatan, pemeliharaan moral kerja serta perlakuan yang sesuai dengan martabat manusia dan moral agama. Perlindungan tersebut bermaksud, agar tenaga kerja secara aman melakukan pekerjaan sehari-hari untuk meningkatkan produksi dan produktivitas nasional. Tenaga kerja harus memperoleh perlindungan dari berbagai soal disekitarnya dan pada dirinya yang dapat menimpa dan mengganggu dirinya serta pelaksanaan pekerjaan.

Keselamatan dan Kesehatan Kerja merupakan salah satu cara untuk melindungi para karyawan dari bahaya kecelakaan kerja. Terkadang pelaksanaan keselamatan dan kesehatan kerja kurang diperhatikan, padahal jika keselamatan dan Kesehatan Kerja dilaksanakan maka akan berpengaruh pada hasil kinerja karyawan. Suasana kerja yang nyaman dan terhindar dari bahaya kecelakaan kerja tentu akan membuat karyawan merasa nyaman dalam bekerja sehingga hasil akan memuaskan.

Berkaitan dengan perlindungan hukum bagi pekerja, menurut Imam Soepomo perlindungan pekerja dibagi menjadi 3 (tiga) macam yaitu:

1. Perlindungan Ekonomis, yaitu jenis perlindungan yang berkaitan dengan usaha-usaha untuk memberikan kepada pekerja suatu penghasilan yang cukup memenuhi sehari-hari baginya beserta keluarganya, termasuk dalam hal ini pekerja tersebut tidak mampu bekerja karena diluar kehendaknya. Termasuk dalam perlindungan ekonomis antara lain perlindungan upah, Jamsostek, dan Tunjangan Hari Raya.

2. Perlindungan Sosial, yaitu perlindungan yang berkaitan dengan usaha kemasyarakatan, yang tujuannya memungkinkan pekerja untuk mengenyam dan memperkembangkan perikehidupannya sebagai manusia pada umumnya dan sebagai anggota masyarakat dan anggota keluarga. Perlindungan sosial ini meliputi perlindungan terhadap buruh anak, buruh perempuan, pengusaha wajib memberi waktu istirahat dan cuti.

3. Perlindungan Teknis, yaitu perlindungan yang berkaitan dengan usaha-usaha untuk menjaga pekerja dari bahaya kecelakaan yang dapat ditimbulkan oleh pesawat-pesawat atau oleh alat kerja lainnya atau bahan-bahan yang diolah atau dikerjakan perusahaan. Perlindungan teknis ini berkaitan dengan Keselamatan dan Kesehatan Kerja, yaitu perlindungan ketenagakerjaan yang berujung agar buruh dapat terhindar dari segala risiko bahaya yang mungkin timbul ditempat kerja baik disebabkan oleh alat atau bahan yang dikerjakan dari suatu hubungankerja. ${ }^{4}$

Ketiga jenis perlindungan diatas mutlak harus dipahami dan dilaksanakan sebaik-baiknyaoleh pengusaha sebagi pemberi kerja. Jika pengusaha melakukan pelanggaran, maka peran pemerintah, pemerintah provinsi dan pemerintah kabupaten/kota untuk melakukan pembinaan dan pengawasan sesuai dengan kewenangannya. Termasuk juga penegakan hukum melalui prosedur dan mekanisme yang berlaku.

\section{METODE}

\section{Pendekatan}

Penelitian ini menggunakan tipe penelitian yuridis empiris dengan pendekatan penelitian yang bersifat analitis dengan maksud memberikan data, menggambarkan masalah yang kemudian menganalisa permasalahan yang ada melalui data-data yang telah dikumpulkan kemudian diolah serta disusun dengan berlandaskan kepada teori-teori dan konsep-konsep yang digunakan. Kemudian melakukan gambaran mengenai masalah yang timbul serta diolah dan disusun berdasarkan teori-teori yang terkait kedalam permasalahan tersebut. Bertujuan untuk memperoleh gambaran secara menyeluruh dan sistematis mengenai Sistem Manajemen Keselamatan Kerja dan kesehatan kerja di Peseroan Terbatas Nilam Sari Cipta Amrizal.

\section{Rancangan Kegiatan}

Penelitian ini dilakukan dengan field research yaitu penelitian langsung yang dilakukan di lapangan untuk memperoleh data yang diperlukan yang berkaitan dengan masalah yang diteliti, di mana penelitian tersebut dilakukan melalui wawancara dengan beberapa pihak yang terkait dengan penelitian ini.

${ }^{4}$ Lihat Asikin dalam Abdul Hakim Hasibuan, Dasar-dasar Hukum Ketenagakerjaan Indonesia, (Bandung: PT.Citra Aditya Bakti, 2014). hlm.102. 


\section{Ruang Lingkup atau Objek}

Sistem Manajemen Keselamatan dan Kesehatan kerja di PT. Nilam Sari Cipta Amrizal

\section{Bahan dan Alat Utama}

1. Data Primer adalah data yang diperoleh langsung dari sumbernya, baik melalui wawancara kemudian diolah oleh peneliti.

2. Data Sekunder adalah data yang diperoleh dari buku, karya tulis ilmiahserta hasil penelitian orang lain yang terkait dengan objek penelitian. Dalam penelitian ini yang merupakan data sekunder antara lain :

a) Undang - Undang No. 1 Tahun 1970 tentang Keselamatan Kerja

b) Undang - Undang No. 13 Tahun 2003 tentang Ketenagakerjaan

c) Undang - Undang No. 36 Tahun 2009 tentang Kesehatan

d) Peraturan Pemerintah No. 50 Tahun 2012 tentang Penerapan Sistem Manajemen Keselamatan dan Kesehatan Kerja

e) Peraturan Menteri tenaga Kerja Nomor Per.05/Men/1996 tentang Sistem Manajemen Keselamatan Dan Kesehatan Kerja.

f) Buku - Buku tentang ketenagakerjaan, pengantar ilmu hukum, jurnal ilmiah dan hasil penelitian lainnya.

\section{Tempat}

Perseroan Terbatas Nilam Sari Cipta Amrizal

\section{Teknik Pengumpulan Data}

Alat pengumpulan data yang dipergunakan dalam penelitian ini adalah wawancara dengan menggunakan pedoman yang telah disediakan. Teknik pengambilan sampel yang digunakan dalam penelitian ini adalah Purposive Sampling adalah teknik penentuan sampel dengan pertimbangan tertentu, dengan kriteria sampel ditetapkan terlebih dahulu kemudian diambil sampel yang memenuhi kriteria. Dalam Penelitian ini yang termasuk dalam populasi adalah karyawan atau pekerja Peseroan Terbatas Nilam Sari Cipta Amrizal berjumlah 42 (empat puluh dua) orang sedangkan sampel yang akan peneliti ambil adalah lima orang pekerja lapangan. Wawancara juga dilakukan melalui narasumber, diantaranya ialah:

(1) Bapak Amrizal, SH. Sebagai direktur utama sekaligus pemilik Perseroan Terbatas. Nilam Sari Cipta Amrizal.

(2) Bapak Ardiansyah (Ahli K3 ) Perseroan Terbatas Nilam Sari Cipta Amrizal.

(3) Ibu Asri Qonita, SH. Bagian administrasi kantor.

(4) Pekerja sebanyak 10 orang.

\section{Defenisi Operasional}

- Sistem manajemen kesehatan di Perseroan Terbatas Nilam Sari Cipta Amrizal adalah Jaminan perlindungan kesehatan bagi karyawan Perseroan Terbatas Nilam Sari Cipta Amrizal yang diukur dengan menggunakan metode wawancara.

- Sistem manajemen keselamatan kerja di Perseroan Terbatas Nilam Sari Cipta Amrizal adalah tersedianya peralatan standar keselamatan kerja berupa sarana dan prasarana alat pelindung diri bagi karyawan Perseroan Terbatas Nilam Sari Cipta Amrizal yang diukur dengan metode wawancara kepada Direktur, ahli K3, staf dan pekerja di Perseroan Terbatas Nilam Sari Cipta Amrizal.

\section{Teknik Analisis}

Data yang diperoleh dari penelitian kepustakaan maupun penelitian dilapangan diolah menggunakan analisis kualitatif yaitu analisis data berdasarkan apa yang diperoleh dari kepustakaan maupun lapangan baik secara lisan maupun tertulis, disajikan dalam bentuk kalimat-kalimat yang logis. Adapun metode yang digunakan adalah metode berpikir induktif yaitu metode berpikir dari ha1-ha1 yang bersifat khusus kemudian ditarik pada satu kesimpulan yang bersifat umum. Penelitian yang telah dilakukan baik secara kepustakaan dan melalui penelitian lapangan disusun secara sitematis dan saling melengkapi kemudian dikaitkan dengan peraturan perundang-undangan yang mengatur mengenai ketenagakerjaan khususnya dalam kaitannya dengan penelitian ini.

\section{HASIL DAN PEMBAHASAN}

Sistem Manajemen Keselamatan dan Kesehatan Kerja di Perseroan Terbatas Nilam Sari Cipta Amrizal.

Sistem Manajemen Keselamatan dan Kesehatan Kerja yang disebut SMK3 adalah bagian dari sistem manajemen secara keseluruhan yang meliputi struktur organisasi, perencanaan, tanggung jawab, pelaksanaan, prosedur, proses dan sumber daya yang dibutuhkan bagi pengembangan, penerapan, pencapaian, pengkajian dan 
pemeliharaan kebijakan K3 dalam rangka pengendalian resiko yang berkaitan dengan kerja guna terciptanya tempat kerja yang aman, efisien dan produktif. Pengusaha dan pengurus tempat kerja harus menetapkan komitmen dan kebijakan K3 serta organisasi K3, menyediakan anggaran dan tenaga kerja dibidang K3. Disamping itu pengusaha dan pengurus juga melakukan koordinasi terhadap perencanaan K3.

Keselamatan dan kesehatan kerja merupakan masalah yang mengandung banyak aspek, misalnya: hukum, ekonomi, maupun sosial. Pelaksanaan keselamatan dan kesehatan kerja di tempat kerja (perusahaaan) dilakukan secara bersama-sama oleh pimpinan atau pengurus perusahaan dan seluruh tenaga kerja. Dalam pelaksanaannya pimpinan atau pengurus dapat dibantu oleh petugas keselamatan dan kesehatan kerja dari tempat kerja atau perusahaan yang bersangkutan. Yang dimaksud dengan petugas keselamatan kerja adalah karyawan yang mempunyai pengetahuan atau keahlian dibidang keselamatan dan kesehatan kerja, dan ditunjuk oleh pimpinan atau pengurus tempat kerja atau perusahaan untuk membantu pelaksanaan usahanya. Sedangkan, yang bertanggung jawab atas keselamatan dan kesehatan kerja di tempat kerja adalah pimpinan atau pengurus tempat kerja/perusahaan atau pengusaha. ${ }^{5}$

Kesehatan Kerja adalah upaya mempertahankan dan meningkatkan derajat kesehatan fisik, mental dan kesejahteraan sosial semua pekerja yang setinggi - tingginya. Mencegah gangguan kesehatan yang disebabkan oleh kondisi pekerjaan; melindungi pekerja dari faktor resiko pekerjaan yang merugikan kesehatan; penepatan dan pemeliharaan pekerja dalam suatu lingkungan kerja disesuaikan dengan kapabilitas fisiologi dan fisiologi dan psikologinya, dan disimpulkan sebagai adaptasi pekerjaan kepada manusia dan setiap manusia kepada pekerjaannya. ${ }^{6}$

Kewajiban pengusaha atau pimpinan perusahaan dalam melaksanakan keselamatan dan kesehatan kerja adalah:

1) Terhadap tenaga kerja yang baru bekerja, ia berkewajiban:

a. Menunjukan dan menjelaskan tentang kondisi dan bahaya yang dapat timbul di tempat kerja, semua alat pengaman dan pelindung yang diharuskan, dan cara dan sikap dalam meakukan pekerjaanya.

b. Memeriksakan kesehatan baik fisik maupun mental tenaga kerja yang bersangkutan.

2) Terhadap tenaga kerja yang telah atau sedang dipekerjakan, ia berkewajiban:

a. Melakukan pembinaan dalam hal pencegahan kecelakaan, penanggulangan kebakaran, pemberian pertolongan pertama pada kecelakaan (P3K) dan peningkatan usaha keselamatan dan kesehatan kerja pada umumnya.

b. Menyediakan secara cuma-cuma semua alat perlindungan diri yang diwajibkan untuk tempat kerja yang bersangkutan bagi seluruh tenaga kerja.

c. Memasang gambar dan Undang-undang keselamatan kerja serta bahan pembinaan lainnya di tempat kerja sesuai dengan petunujuk pegawai pengawas atau ahli keselamatan dan kesehatan kerja.

d. Melaporkan setiap peristiwa kecelakaan termasuk peledakan, kebakaran dan penyakit akibat kerja yang terjadi di tempat kerjatersebut kepada Kantor Departemen Tenaga Kerja setempat.

e. Membayar biaya pengawasan keselamatan dan kesehatan kerja ke Kantor Perbendaharaan Negara setemoat setelah mendapat penetapan besarnya biaya oleh Kantor Wilayah Departemen Tenaga Kerja setempat.

f. Mentaati semua persyaratan keselamatan dan kesehatan kerja baik yang diatur dalam peraturan perundangundangan maupunyang ditetap oleh pengawas. ${ }^{7}$

Pelaksanaan pengawasan keselamatan dan kesehatan kerja dilakukan oleh:

a. Pegawai pengawas keselamatan dan kesehatan kerja ;

b. Ahli keselamatan kerja;

c. Pengawas ketenagakerjaan terpadu (umum dan spesialis).

Sedangkan yang berhak melakukan pemeriksaaan kesehatan pekerja adalah dokter yagn ditunjuk oleh pimpinan tempat kerja/perusahaan dan yang disetujui oleh Departemen Tenaga Kerja. Konsep budaya kerja yang dimaksud dalam rangka ini adalah refleksi sistenm nilai pokok yang di adopsi oleh perusahaan tertentu. Budaya yang demikianitu diwujudkan dalam praktek sebagai sistem manajemen, kebijakan personalia, prinsip partisipasi, kebijakan pelatihan dan manajemen mutu perusahaan. Dalam Undang-undang No. 36 tahun 2009 tentang Kesehatan pasal 164 disebutkan bahwa: Kesehatan kerja ditunjukan untuk melindungi pekerja agar hidup sehat dan terbebas dari gangguan kesehatan serta pengaruh buruk yang diakibatkan oleh pekerjaan. Pengelola tempat kerja wajib melakukan segala bentuk upaya kesehatan melalui upaya pencegahan, peningkatan, pengobatan dan pemulihan bagi tenaga kerja.

Peraturan Pemerintah No. 50 Tahun 2012 tentang Penerapan SMK3 dijelaskan pula bahwa SMK3 adalah bagian dari sistem manajemen perusahaan secara keseluruhan dalam rangka pengendalian risiko yang berkaitan dengan kegiatan kerja guna terciptanya manajemen perusahaan yang teratur dan saling berhu bungan untuk mencapai tujuan produktivitas perusa haan yang telah ditetapkan terkait dengan K3. Undang-Undang Nomor 13 Tahun 2003 tentang Ketenagakerjaan pasal 87 (1)

\footnotetext{
${ }^{5}$ Lalu Husni, Pengantar Hukum Ketenagakerjaan Indonesia, Jakarta : Rajawali Press.2015. hlm.135.

${ }^{6}$ L. Meily Kurawidjaja, Teori dan Aplikasi Kesehatan Kerja, Jakarta: Universitas Indonesia,2010.hlm. 45.

${ }^{7}$ Swandjun H. Manulang, Pokok-pokok Hukum Ketenagakerjaan di Indonesia, (Jakarta:Rineka Cipta,2001), hlm.83.
} 
dinyatakan bahwa setiap perusahaan wajib menerapkan Sistem Manajemen K3 yang terintegrasi dengan sistem manajemen perusahaan.

Dalam penerapan Sistem Manajemen Keselamatan dan Kesehatan Kerja, terdapat lima (5) prinsip dasar yang harus diterapkan oleh perusahaan adalah:

1. Penetapan kebijakan Keselamatan dan Kesehatan Kerja.

Pengusaha dalam menyusun kebijakan Keselamatan dan Kesehatan Kerja adalah:

a. Melakukan tinjauan awal kondisi Keselamatan dan Kesehatan Kerja meliputi :

(1) Identifikasi potensi bahaya, penilaian dan pengendalian risiko;

(2) Perbandingan penerapan Keselamatan dan Kesehatan Kerja dengan perusahaan dan sektor lain yang lebih baik;

(3) Peninjauan sebab akibat kejadian yang membahayakan;

(4) Kompensasi dan gangguan serta hasil penilaian sebelumnya yang berkaitan dengan keselamatan; dan

(5) Penilaian efisiensi dan efektivitas sumber daya yang disediakan.

b. Memperhatikan peningkatan kinerja manajemen Keselamatan dan Kesehatan Kerja secara terus - menerus; dan

c. Memperhatikan masukan dari pekerja / buruh dan / atau serikat pekerja / serikat buruh.

Kebijakan Keselamatan dan Kesehatan Kerja memuat visi; tujuan perusahaan; komitmen dan tekad melaksanakan kebijakan; dan kerangka dan program kerja yang mencakup kegiatan perusahaan secara meyeluruh yang bersifat umum dan atau operasional.

2. Perencanaan Keselamatan dan Kesehatan Kerja.

Yang harus dipertimbangkan dalam menyusun rencana Keselamatan dan Kesehatan kerja adalah:

a. Hasil penelaahan awal;

b. Indentifikasi bahaya, penilaian dan pengendalian risiko;

c. Peraturan perundang-undangan dan persyaratan lainnya; dan

d. Sumber daya yang dimiliki.

3. Pelaksanaan rencana Keselamatan dan Kesehatan Kerja

Dalam melaksanakan rencana Keselamatan dan Kesehatan Kerja didukung oleh sumber daya manusia dibidang Keselamatan dan Kesehatan Kerja, prasarana, dan sarana. Sumber daya manusia harus memiliki :

a. Kompetisi kerja yang dibuktikan dengan sertifikat; dan

b. Kewenangan di bidang Keselamatan Dan Kesehatan Kerja yng dibuktikan dengan surat izi kerja atau operasi atau surat penunjukkan dari instasi yang berwenang.

Prasarana dan sarana terdiri dari:

a. Organisasi atau unit yang bertanggung jawab di bidang Keselamtan dan Kesehatan Kerja

b. anggaran yang memadai;

c. prosedur operasi kerja, inforomasi, dan pelaporan serta pendokumentasian; dan

d. Instruksi kerja.

Dalam melaksanakan rencana Keselamatan dan Kesehatan Kerja harus melakukan kegiatan dalam pemenuhan persyaratan Keselamatan dan Kesehatan Kerja. Kegiatan tersebut adalah :

1) Tindakan pengendalian

2) Perancangan dan rekaya;

3) Prosedur dan instruksi kerja;

4) Penyerahan sebagian pelaksanaan pekerjaan;

5) Pembelian atau pengadaan barang dan jasa;

6) Produk akhir;

7) Upaya menghadapi keadaan darurat kecelakaan dan bencana industry; dan

8) Rencana dan pemulihan keadaan darurat

4. Pemantauan dan Evaluasi Kinerja Keselamatan dan Kesehatan Kerja

a) Melalaui pemeriksaan, pengujian,pengukuran dan audit internal Sistem Manajemen Keselamatan dan Kesehatan Kerja dilakukan oleh sumber daya manusia yang kompeten.

b) Dalam hal perusahaan tidak mempunyai Sistem Manajemen dan Kesehatan Kerja dapat menggunakan pihak lain.

c) Hasil pemantauan dilaporkan kepada pengusaha.

d) Hasil tersebut digunakan untuk melukukan tindakan pengendalian.

e) Pelaksanaan pematauan dan Evaluasi dilakukan berdasarkan peraturan Perundang-undangan.

5. Peninjauan dan Peningkatan Kinerja Sistem Manajemen dan Kesehatan Kerja.

a) Untuk menjamin kesesuai dan efektifitas penerapan Sistem Manajemen dan Keselamatan Kerja, dilakukan peninjauan terhadap kebijakan, perencanaan, pelaksanaan, pemantauan dan evaluasi. 
b) Hasil peninjauan digunakan untuk perbaikan dan peningkatan kinerja.

c) Perbaikan dan Peningkatan kinerja dilaksanakan dalam hal :

(1) Terjadi perubahan peraturab perundang-undangan;

(2) adanya tuntutan dari pihak yang terkait dan pasar;

(3) adanya perubahan produk dan kegiatan perusahaan;

(4) terjadi perubahan struktur organisasi perusahaan;

(5) adanya perkembangan ilmu pengetahuan dan teknologi, termasuk epidemiologi;

(6) adanya hasil kajian kecelakaan ditempat kerja;

(7) asasnya pelaporan; dan atau

(8) adanya masukan dari pekerja atau buruh. ${ }^{8}$

Demikianlah prinsip dasar yang dijadikan sebagai oleh perusahaan dalam melaksanakan Sistem Manajemen K3.Dari ketentuan tersebut dapat disimpulkan bahwa Sistem Manajemen Keselamatan dan Kesehatan Kerja yang disebut SMK3 adalah bagian dari sistem manajemen secara keseluruhan yang meliputi struktur organisasi, perencanaan, tanggung jawab, pelaksanaan, prosedur, proses dan sumber daya yang dibutuhkan bagi pengembangan, penerapan, pencapaian, pengkajian dan pemeliharaan kebijakan K3 dalam rangka pengendalian resiko yang berkaitan dengan kerja guna terciptanya tempat kerja yang aman, efisien dan produktif. Pengusaha dan pengurus tempat kerja harus menetapkan komitmen dan kebijakan K3 serta organisasi K3, menyediakan anggaran dan tenaga kerja dibidang K3. Disamping itu pengusaha dan pengurus juga melakukan koordinasi terhadap perencanaan K3. Dengan demikian kewajiban perusahaan bukan hanya sekedar menyediakan fasilitas atau untuk penerapan K3 saja, tetapi juga wajib mengaturnya secara terintegrasi dalam sistem manajemen perusahaan. Mulai dari menetapkan komitmen, perencanaan, sampai kepada prosedur penggunaan perlengkapan untuk penerapan K3 wajib diatur dan dibuat secara teratur dan terorganisir sesuai ketentuan peraturan perundang-undangan.

Perseroan Terbatas Nilam Sari Cipta Amrizal yang mulai menjalankan usahanya sejak tahun 2015 berdasarkan dengan akta pendiriannya November 2015. Perseroan Terbatas Nilam Sari Cipta Amrizal menjalankan berbagai kegiatan usaha sebagaimana dicantumkan pada akta pendiriannya. Salah satu kegiatan usaha Perseroan Terbatas Nilam Sari Cipta Amrizal yaitu pembangunan serta pemasangan instalasi penyediaan tenaga listrik. PerseroanTerbatas Nilam Sari Cipta Amrizal mempekerjakan 42 ( empat puluh dua) orang karyawan yang terdiri dari karyawan tetap, karyawan tidak tetap yang terbagi pula sebagai pekerja lapangan, pelaksana gudang dan tenaga adminitrasi / kantor, sebagaimana dirinci pada tabel 1 dibawah ini .

Tabel 1. Jumlah karyawan Perseroan Terbatas Nilam Sari Cipta Amrizal

\begin{tabular}{|c|c|c|c|c|c|c|c|c|}
\hline \multicolumn{9}{|c|}{ DATA KARYAWAN PT.NILAM SARI CIPTA AMRIZAL } \\
\hline \multirow{2}{*}{ NO } & Pelaksana Pekerjaan Di Lapagan & \multirow{2}{*}{ No } & \multicolumn{2}{|c|}{ Pelaksana di Gudang } & No & \multicolumn{2}{|c|}{ Kantor/administrasi } \\
\cline { 2 - 5 } \cline { 5 - 8 } & Jumlah & Status & Jumlah & Status & & Jumlah & Status \\
\hline 1 & 14 orang & Karyawan Tetap & 1 & 10 orang & Karyawan Tetap & 1 & 2 orang & Karyawan Tetap \\
\hline 2 & 16 orang & Karyawan tidak tetap & & & & & \\
\hline \multicolumn{3}{|c|}{ Jumlah seluruh karyawan 42 orang, 26 karyawan tetap, 16 orang karyawan tidak tetap } \\
\hline
\end{tabular}

Sumber Data : PT.NSCA Pebruari tahun 2020

Mengingat bidang pekerjaannya selalu berhubungan dengan arus listrik, kadang berhubungan dengan ketinggian karena harus melakukan pekerjaan pada tiang listrik, tentu saja memiliki potensi (kecelakaan) tinggi. Peseroan Terbatas Nilam Sari Cipta Amrizal dalam menjalankan kegiatannya selalu mengutamakan keselamatan dan kesehatan kerja karyawannya, sebagaimana hasil wawancara dengan Bapak Amrizal, SH. selaku pemilik Peseroan Terbatas Nilam Sari Cipta Amrizal, menuturkan: "tentang keselamatan dan kesehatan kerja dalam perusahaan ini sudah kami upayakan. Untuk keselamatan kerjanya kami sudah menyediakan alat - alat pelindung, seperti helm, sarung tangan, sepatu, pelindung mata, masker, dan sabuk pengaman apabila mereka bekerja di ketinggian. Bersyukur mereka dengan penuh kesadaran mau menggunakannya tanpa harus dipaksa." 9

Sama halnya dengan yang dikatakan oleh bapak Ardiansyah, yang bertugas sebagai Ahli K3, beliau mengatakan :" pihak perusahaan sudah menyediakan alat perlindungan kerja. mereka (pekerja) mau memakainya, alasannya demi keselamatan diri sendiri."10 Berdasarkan hasil wawancara dengan direktur Peseroan Terbatas Nilam Sari Cipta Amrizal dan ahli K3 bahwa K3 sudah dilaksanakan. Perusahaan sudah menyediakan Alat Pelindung Diri (APD) bagi karyawannya ketika menjalankan pekerjaan dan karyawan dengan kesadaran sendiri mau menggunakannya. Hal

${ }^{8}$ Lihat PP No.50 Tahun 2012 tentang Sistem Manajemen Keselamatan Kerja.

${ }^{9}$ Amrizal, SH. Direktur PT.NSCA, wawancara, tgl 26 Agustus 2020.

${ }^{10}$ Adiansyah, Ahli K3 PT.NSCA, wawancara, tgl 26 Agustus 2020. 
senada juga dikemukakan oleh Asri Qonita, SH, staf administrasi Peseroan Terbatas Nilam Sari Cipta Amrizal bahwa " perusahaan sudah menyediakan kelengkapan peralatan K3 dan para pekerja / karyawan dengan kesadaran sendiri mau menggunakannya tanpa harus dipaksa ". ${ }^{11}$ Data kelengkapan K3 pada Peseroan Terbatas Nilam Sari Cipta Amrizal dapat dilihat pada tabel 2 berikut ini.

Tabel 2. Kelengkapan Peralatan K3 Peseroan Terbatas Nilam Sari Cipta Amrizal

\begin{tabular}{|c|l|l|c|c|}
\hline No & Jenis Peralatan & Satuan & Jumlah Minimal & Jumlah Yang Dimiliki \\
\hline 1 & Helm Standar & Buah & 5 & 12 \\
\hline 2 & Full Body Hamess/Double Safety Hamess & set & 5 & 12 \\
\hline 3 & Sepatu pengaman Kerja & pasang & 5 & 12 \\
\hline 4 & Sarung Tangan Isolasi 20 KV & pasang & 5 & 5 \\
\hline 5 & Sepatu Isolasi 20 KV & pasang & 5 & 5 \\
\hline 6 & Rambu Tanda Lokasi Kerja & set & 2 & 2 \\
\hline 7 & Jas Hujan & buah & 5 & 14 \\
\hline 8 & Sarung tangan kulit untuk JTR & pasang & 5 & 10 \\
\hline 9 & Kacamata & buah & 5 & 8 \\
\hline 10 & P3K & buah & 1 & 1 \\
\hline
\end{tabular}

Sumber Data : PT.NSCA, Pebruari 2020.

Dari tabel tersebut tergambar bahwa Peseroan Terbatas Nilam Sari Cipta Amrizal mempunyai peralatan K3 sudah sesuai bahkan sebagian besar alat yang tersedia jumlahnya sudah melebihi standar minimal yang ditentukan oleh peraturan perundang-undang dan instansi terkait.

Karyawan Peseroan Terbatas Nilam Sari Cipta Amrizal sangat menyadari bahwa pentingnya menggunakan Peralatan K3 demi untuk keselamatan mereka sendiri. Hal utama yang harus mereka siapkan sebelum menuju lokasi proyek adalah menyiapkan perlengkapan K3 dengan bantuan pelaksana gudang. Apabila perlengkapan sudah diberikan oleh pelaksana gudang baru mereka berangkat menuju lokasi proyek. Kesadaran karyawan Peseroan Terbatas Nilam Sari Cipta Amrizal untuk melakukan perlindungan diri cukup tinggi sebagaimana hasil wawancara dengan pekerja lapangan pada tabel 3 dibawah ini:

Tabel 3. Penggunaan Perlengakapan K3

\begin{tabular}{|c|l|c|c|c|}
\hline No & \multicolumn{1}{|c|}{ Nama } & Menggunakan alat perlengkapan K3 & Tidak Menggunakan alat perlengkapan K3 & Alasan \\
\hline 1 & Lukman & $\checkmark$ & & Sudah kewajiban \\
\hline 2 & Ahmad Lutfi & $\checkmark$ & & SOP \\
\hline 3 & Aldi & $\checkmark$ & & Demi keselamatan \\
\hline 4 & Hendra & $\checkmark$ & & Sudah kewajiban \\
\hline 5 & Robi & $\checkmark$ & & kewajiban \\
\hline 6 & Zakaria & $\checkmark$ & & Demi keselamatan \\
\hline 7 & Herman & $\checkmark$ & & SOP \\
\hline 8 & Sunarto & $\checkmark$ & & kesadaran \\
\hline 9 & Irwandi & $\checkmark$ & kewajiban \\
\hline 10 & Sanusi & $\checkmark$ & kesadaran \\
\hline
\end{tabular}

Sumber Data : hasil wawancara agustus 2020.

Mencegah dan melindungi tenaga kerja dari gangguan kesehatan yang disebabkan oleh kondisi lingkungan kerja. Dari hasil wawancara kepada para pekerja lapangan yang berhubungan langsung dengan tingkat risiko, mereka dengan penuh kesadaran mau menggunakan alat perlengkapan K3 sebagai suatu kewajiban.

Peseroan Terbatas Nilam Sari Cipta Amrizal belum menyusun dokumen K3 yang mempunyai identifikasi status, wewenang, tanggal pengeluaran dan tanggal modifikasi. Berdasarkan PP No. 50 Tahun 2012 tentang Sistem Manajemen Keselamatan dan Kesehatan Kerja, perusahaan harus mempunyai dan mengembangkan sistem pendokumentasian yang efisien. Dokumen harus mudah diakses, dan dipelihara dengan sebaik-baiknya. Perusahaan yang belum mendokumentasikan prosedur, maka perusahaan harus mempunyai dokumen formal berupa Standard Operating Procedur (SOP) tentang penyimpanan, penanganan, dan pemindahan serta penggunaan peralatan K3. Penerapan Sistem Manajemen K3 pada Perseroan Terbatas Nilam Sari Cipta Amrizal sudah dilakukan namun hanya secara kebiasaan dan lisan saja tanpa dibuat Standard Operating Procedur (SOP) secara tertulis, sebagaimana dikemukakan oleh Asri Qonita, SH. sebagai staf administrasi : "Peseroan Terbatas Nilam Sari Cipta Amrizal belum mempunyai SOP tentang prosedur penggunaan alat perlengkapan K3. Untuk sekarang tentang penggunaan dan

${ }^{11}$ Asri Qonita, SH, staf administrasi PT.NSCA, wawancara, 20 Februari 2020. 
kewajiban memakai perlengkapan K3 disampaikan secara lisan oleh pimpinan atau oleh komando pekerja lapangan." 12

Dari pemaparan diatas dapat diketahui bahwa Perseroan Terbatas Nilam Sari Cipta Amrizal sudah menyelenggarakan upaya keselamatan dan kesehatan kerja. Dengan cara menyediakan alat pelindung diri untuk para pekerjanya. Dari pemaparan di atas dapat diketahui bahwa meskipun perusahaan belum mempunyai SOP secara tertulis, tetapi para karyawan lapangan sudah terbiasa menggunakan alat perlengkapan K3 dengan penuh kesadaran sebagai suatu kewajiban. Namun demikian sebaiknya disediakan sarana untuk melihat SOP setiap kali mereka akan menggunakan alat tersebut supaya tidak salah prosedur atau lupa cara penggunaannya, karena keceakaan kerja dapat terjadi disebabkan berbagai faktor bukan hanya ketersediaan alatnya saja.

Membahas mengenai keselamatan kerja, yaitu kecelakaan yang terjadi di tempat kerja atau dikenal dengan istilah kecelakaan industri. Ada 4 (empat) faktor penyebab dari kecelakaan industri atau kecelakaan kerja ini, yaitu :

a. Faktor manusianya

Kurangnya keterampilan atau kurangnya pengetahuan.

b. Faktor material bahannya dan peralatan misalnya bahan yang seharusnya terbuat dari besi akan tetapi supaya lebih murah dibuat dari bahan lainnya sehingga dapat dengan mudah menimbulkan kecelakaan.

c. Faktor bahaya atau sumber bahaya, ada dua sebab :

(1) Perbuatan berbahaya. Misalnya karena metode kerja yang salah, keletihan, sikap kerja yang tidak sempurna dan sebagainya.

(2) Kondisi /keadaan berbahaya. Yaitu keadaan yang tidak aman dari mesin/peralatan, lingkungan, proses, sifat pekerjaan.

d. Faktor yang dihadapi

Misalnya kurangnya pemeliharaan /perawatan mesin-mesin atau peralatan lainnya sehingga tidak bisa bekerja dengan sempurna.

Kesehatan kerja juga tidak kalah penting dari keselamatan kerja. Keduanya saling berkesinambungan. Tujuan kesehatan kerja adalah :

a. Meningkatkan dan memelihara derajat kesehatan tenaga kerja yang setinggi-tingginya baik fisik, mental maupun sosial.

b. Menyesuaikan tenaga kerja dengan pekerjaan atau pekerjaan dengan tenaga kerja.

c. Meningkatkan produktivitas kerja. ${ }^{13}$

Dengan demikian penerapan K3 pada suatu perusahaan bukan hanya untuk kepentingan keselamatan dan kesehatan pekerjanya saja tetapi juga bermanfaat untuk kepentingan perusahaan. Apabila karyawan / pekerja bekerja dengan lingkungan yang sehat, peralatan yang memadai sehingga mereka nyaman melakukan pekerjaannya yang pada akhirnya produktivitas kerja tidak terganggu bahkan mereka dapat lebih meningkatkan produktivitas kerjanya.

Penerapan Sistem Manajemen K3 pada Perseroan Terbatas Nilam Sari Cipta Amrizal sebagaimana uraian hasil penelitian diatas bahwa perusahaan ini belum menerapkan SOP secara tertulis dan jika ada karyawan yang belum menerapkan standar keamanan dalam menjalankan pekerjaannya, pimpinan atau pengawas lapangan langsung mengingatkan secara lisan. Namun ada baiknya perusahaan membuat aturan secara tertulis dengan sanksi yang tegas sehingga karyawan akan lebih patuh menjalankan SOP yang telah ditetapkan. Dengan demikian pencegahan kecelakaan kerja lebih dini dilakukan yang pada akhirnya pekerjaan terlaksana dengan aman dan efisien, sebagaimana dikemukan pada kutipan dibawah ini.

Penerapan aspek hukum terhadap Keselamatan dan Kesehatan Kerja akan berpengaruh baik kepada perusahaan maupun tenaga kerja, karena apabila perusahaan maupun tenaga kerja yang mengabaikan K3 dalam menjalankan pekerjaan akan diberikan sanksi hukum karena baik perusahaan maupun tenaga kerja telah terikat secara hukum. Sebagai contoh apabila para pekerja pada saat melakukan pekerjaan diketinggian dan tidak menggunakan Sabuk Pengaman maka safety officer dapat memberikan sanksi kepada pekerja tersebut sesuai dengan aturan yang dibuat oleh perusahaan. ${ }^{14}$ Menerapkan K3 sesuai dengan peraturan perundang-undangan secara tidak langsung perusahaan dapat mencegah terjadinya kecelakaan dan penyakit kerja serta pelanggaran kerja. Dan juga pekerjaan dapat terlaksana dengan aman dan efisien.

${ }^{12}$ Asri Qonita, SH. Staf Administrasi, wawancara, 20 Pebruari 2020.

${ }^{13}$ Senjun H. Manulang, Pokok-pokok Hukum Ketenagakerjaan di Indonesia, (Jakarta:Rineka Cipta,2001),hlm.87

14 Christie Pricilia Pelealu, Jermias Tjakra, B.F.Sompie, "Penerapan Aspek Hukum Terhadap Keselamatan Dan Kesehatan Kerja ( Studi Ksus: Proyek The Lagoon Taman Sari Bahu Mall)”, Jurnal Sipil Statik, Vol.3.No.5 Mei 2015 (331-340) ISSN.2337-6732, hlm. 338. 


\section{Kendala Sistem Manajemen Keselamatan dan Kesehatan Kerja Di Peseroan Terbatas Nilam Sari Cipta Amrizal.}

Pada kenyataannya, Peseroan Terbatas Nilam Sari Cipta Amrizal sudah melaksanakan keselamatan dan kesehatan kerja sesuai dengan amanat Peraturan Pemerintah Nomor 50 tahun 2012 tentang Sistem Manajemen Keselamatan dan Kesehatan Kerja, bahwa setiap perusahaan yang mempunyai tingkat potensi bahaya tinggi wajib menerapkan sistem keselamatan dan kesehatan kerja namun belum terintegrasi dengan sistem manajemen perusahaan secara keseluruhan. Dalam hal ini perusahaan tersebut tidak membuat peraturan perusahaan secara tertulis dan juga belum menerapkan sistem manajemen keselamatan dan kesehatan kerja.

Peseroan Terbatas Nilam Sari Cipta Amrizal. menjelaskan alasan belum menerapkan sistem manajemen keselamatan dan kesehatan kerja sampai saat ini adalah karena perusahaan mempekerjakan tenaga kerja hanya berjumlah 42 orang dan pekerja lapangan hanya 30 orang dengan status pekerja tidak tetap 16 orang. Perusahaan sudah merasa cukup dalam menerapkan keselamatan dan kesehatan kerja dengan menyediakan alat perlengkapan K3, jadi tidak perlu menerapkan sistem manajemen keselamatan dan kesehatan kerja. Intinya yang penting mereka sudah melindungi pekerjanya dari bahaya kemungkinan kecelakaan kerja. Seperti yang telah dituturkan oleh Ardiansyah , selaku Ahli K3 :

"kami belum menerapkan sistem manajemen keselamatan dan kesehatan kerja, karena bagi kami sudah melakukan beberapa usaha agar tempat pengerjaan proyek itu aman, dan tidak menimbulkan bahaya untuk para pekerja dan sekitarnya, pekerja sudah menggunakan alat perlengkapan K3 dengan baik." 15

Penerapan Sistem Manajemen Keselamatan dan Kesehatan Kerja (SMK3) yang diatur oleh Peraturan Pemerintah Nomor 50 Tahun 2012 yaitu: (1) Pembangunan dan pemeliharaan komitmen, (2) Pembuatan \& pendokumentasian rencana K3, (3) Perancangan dan peninjauan kontrak, (4) Pengendalian dokumen, (5) Pembelian dan pengendalian produk, (6) Keamanan bekerja berdasarkan SMK3, (7) Standar pemantauan, (8) Pelaporan dan perbaikan kekurangan, (9) Pengelolahaan material dan perpindahannya, (10) Pengembangan keterampilan dan kemampuan.

Pengusaha dan Pengurus menunjukan komitmennya melalui yaitu :

a. Membentuk Organisasi Keselamatan dan Kesehatan Kerja

b. Menyediakan anggaran sarana dan tenaga kerja diperlukan dalam bidang Keselamatan dan Kesehatan Kerja

c. Menetapkan personel yang mempunyai tanggung jawab dan wewenanng yang jelas dalam penanganan Keselamatan dan Kesehatan Kerja

d. Melakukan perencanaan dan penilitian kinerja Keselamatan dan Kesehatan Kerja.

Perseroan Terbatas Nilam Sari Cipta Amrizal sudah menerapkan Sistem Manajemen Keselamatan Dan Kesehatan Kerja (K3) namun belum sepenuhnya sesuai dengan yang diatur dalam peraturan pemerintah. Kendala yang dihadapi oleh Peseroan Terbatas Nilam Sari Cipta Amrizal dalam penerapan Sistem Manajemen Keselamatan Dan Kesehatan Kerja, diantaranya:

a. Masih Kurangnya Pemahaman Pekerja khususnya tentang sistem manajemen K3 sehingga terkadang harus diperingatkan untuk patuh menggunakan peralatan K3 yang sudah disediakan dengan benar sesuai standar K3.

b. Menganggap Penerapan Sistem Manajemen Keselamatan dan Kesehatan Kerja tidak perlu dilakukan dalam bentuk SOP secara tertulis, karena selama ini sudah berjalan dengan baik walaupun dilakukan petunjuk secara lisan saja.

c. Jumlah personil masih terbatas untuk khusus mengurus peralatan K3.

\section{Upaya yang dilakukan Untuk Mengatasi Kendala Sistem Manajemen Keselamatan dan Kesehatan Kerja di Peseroan Terbatas Nilam Sari Cipta Amrizal.}

Untuk mengendalikan potensi bahaya di tempat kerja adalah dengan melakukan peninjauan pada sumbernya. Hal ini dapat dilakukan oleh perusahaan dengan mengelola atau menghilangkan bahaya semaksimal mungkin. Beberapa hal yang dapat dilakukan Perseroan Terbatas Nilam Sari Cipta Amrizal dengan cara menyediakan Alat Pelindung Diri (APD) untuk meminimalkan risiko dan potensi bahaya di lingkungan kerja. Perseroan Terbatas Nilam Sari Cipta Amrizal membekali para pekerja dengan pemahaman dan wawasan yang baik mengenai akibat dari potensi bahaya yang dapat terjadi di tempat kerja.

Peseroan Terbatas Nilam Sari Cipta Amrizal menyediakan Alat Pelindung Diri yang sesuai untuk pekerja dan melatih pekerja dalam menggunakan dan merawat Alat Pelindung Diri. Merawat dan mengganti Alat Pelindung Diri yang rusak secara berkala. Meninjau dan dan mengevaluasi efektifitas program pemakain Alat Pelindung Diri.

Selain menyediakan alat perlidung diri secara cuma-cuma, yang diwajibkan pada tenaga kerja, Peseroan Terbatas Nilam Sari Cipta Amrizal melakukan pembinaan tentang peraturan pelaksanaan yang berlaku ditempat kerja yaitu:

${ }^{15}$ Ardiansyah, Ahli K3 PT NSCA, wawancara 26 Agustus 2020. 
a. Melakukan pengarahan kepada para pekerja sebelum melakukan pekerjaan seperti selalu mengingatkan untuk memakai alat pelindung diri untuk keselamatan.

b. Membagi tugas sesuai keahlian masing-masing pekerja.

c. Menunjukkan bagaimana menggunakan alat kerja yang baik dan benar dan selalu memperingati untuk selalu berhati-hati dalam bekerja.

d. Melakukan Evaluasi setelah pekerjaan selesai, hal tersebut untuk semua pekerja baik yang baru ataupun yang lama.

Berikut penuturan Bapak Amrizal, Direktur Peseroan Terbatas Nilam Sari Cipta Amrizal, sebagai berikut:

"usaha kami untuk menciptakan lingkungan kerja yang aman, jauh dari kemungkinan bahaya kecelakaan kerja adalah menyediakan kelengkapan pakaian keselamatan kerja/alat-alat pelindung diri, seperti helm, sabuk pengaman, sarung tangan, masker, sepatu. Selain itu kami selalu siapkan P3K (Pertolongan Pertama Pada Kecelakaan), serta pengenalan mengenai keselamatan dan kesehatan kerja sejak mereka bergabung dengan perusahaan ini. Pengenalan keselamatan dan kesehatan kerja tersebut dilakukan oleh ahli K3 dan pekerja Peseroan Terbatas Nilam Sari Cipta Amrizal yang sudah pernah mengikuti sosialisasi keselamatan dan kesehatan kerja di Disnaker Kota Jambi." 16

Dalam Undang-Undang Ketenagakerjaan sanksi pelanggaran terhadap Keselamatan dan Kesehatan Kerja yang diatur adalah mengenai sanksi administrasi, yakni dalam pasal 190 Undang-Undang No. 13 Tahun 2003 tentang Ketenagakerjaan, yang meliputi sebagai berikut:

1) Menteri atau pejabat yang ditunjuk mengenakan sanksi administrasi atas pelanggaran ketentuan - ketentuan senagaimana diatur dalam Pasal 5, Pasal 6, Pasal 15, Pasal 25, Pasal 38 atas (2), Pasal 45 ayat (1), Pasal 47 ayat (1), Pasal 48, Pasal 87, Pasal 106, Pasal 126 ayat (3), dan Pasal 160 ayat (10) dan ayat (2) Undang - Undang ini serta peraturan pelaksanaan.

2) Sanksi administrasi sebagaiman dimaksud dalam ayat (1) berupa:
a. Teguran;
b. Peringat tertulis;
c. Pembekuan kegiatan usaha;
d. Pembatalan persetujuan;
e. Pembatalan pendaftaran;
f. Penghentian sementara sebagain atau seluruh alat produksi;
g. Pencabutan izin.

3) Ketentuan mengenai sanksi administrasi sebagaimana dimaksud dalam ayat (1) dan ayat (2) diatur lebih lanjut ole Menteri.

Adapun mengenai sanksi pidana Keselamatan mengenai sanksi pidana Keselamatan dan Kesehatan Kerja pada pasal 15, yaitu :

a. Pelaksanaan ketentuan tersebut pada pasal-pasal di atas diatur lebih lanjut dengan peraturan perundangan.

b. Peraturan perundangan tersebut pada ayat (1) dapat memberikan acaman pidana atas pelannggaran peraturanya dengan hukuman kurungan selama- lamanya 3 (tiga) bulan atau denda setingginya Rp. 100.000,- (seratus ribu rupiah )

c. Tindak pidana tersebut adalah pelanggaran. Aturan ini masih berlaku hingga sekarang dan menjadi dasar dalam penetapan perlindungan Keselamatan dan Kesehatan Kerja.

Manfaat bagi pemerintah Penerapan Sistem Manajemen Keselamatan dan Kesehatan adalah sebagai salah satu upaya untuk melindungi hak tenaga kerja dibidang keselamatan dan kesehatan kerja, meningkatkan mutu kehidupan bangsa dan image bangsa di forum internasional, mengurangi angka kecelakaan kerja yang sekaligus akan meningkatkan produktifitas kerja dan mengetahui tingkat penerapan terhadap peraturan perundangan.

\section{SIMPULAN}

Berdasarkan penelitian yang telah dilaksanakan, dapat diambil sebuah kesimpulan dari pembahasan penelitian ini adalah sebagai berikut :

1. Pelaksanaan perlindungan keselamatan dan kesehatan kerja bagi pekerja di Peseroan Terbatas Nilam Sari Cipta Amrizal adalah dengan melaksanakan upaya pencegahan kecelakaan kerja, yaitu dengan menyediakan alat perlengkapan K3 dengan jumlah yang memadai. Hal tersebut merupakan bentuk pemenuhan dari salah satu hak pekerja yang tercantum dalam pasal 87 ayat (1) Undang - Udang No. 13 Tahun 2003 tentang Ketenakerjaan. Namun pelaksanaan perlindungan keselamatan dan kesehatan kerja perusahaan belum memiliki SOP secara tertulis.

\footnotetext{
${ }^{16}$ Amrizal, SH. Direktur PT.NSCA, wawancara, 26 Agustus 2020.
} 
2. Kendala yang dihadapi oleh Peseroan Terbatas Nilam Sari Cipta Amrizal dalam melaksanakan sistem Manajemen Keselamatan dan Kesehatan Kerja, masih ada pekerja yang belum sepenuhnya memahami tentang penggunaan peralatan K3 dengan benar. Hal ini kemungkinan dikarenakan belum dibuatnya SOP secara tertulis karena selama ini sudah berjalan dengan baik walaupun dilakukan petunjuk secara lisan saja.

3. Melakukan pengarahan kepada para pekerja sebelum melakukan pekerjaan seperti selalu mengingatkan untuk memakai alat pelindung diri atau keselamatan.

\section{DAFTAR PUSTAKA}

\section{Buku}

Hadjon, Philipus M, Perlindungan Hukum Dalam Negara Hukum Pancasila, Bandung: Armico 2003.

Husni, Lalu, Pengantar Hukum Ketenagakerjaan Indonesia.Jakarta : Rajawali Press, 2015.

Khakim, Abdul, Dasar Dasar Hukum Ketenagakerjaan indonesia, Bandung : PT. Citra Aditya Bakti, 2014.

Kurawidjaja, Meily, Teori dan Aplikasi Kesehatan Kerja, Jakarta: Universitas Indonesia, 2010.

Manulang, Swandjun H, Pokok-Pokok Hukum Ketenagakerjaan di Indonesia, Jakarta: PT Rineka Cipta, 2001.

Mulhadi, Hukum Perusahaan, Jakarta : PT. Raja Grafindo Persada, 2016.

Nasution, Bahder Johan, Metode Penelitian Hukum, Bandung: Mandar Maju, 2008.

Silaban, Gerry dan Salomo Perangin-angin, Hak Dan Atau Kewajiban Tenaga Kerja Dan Pengusaha/Pengurus Yang Ditetapkan Dalam Peraturan Perundangan Keselamatan Dan Kesehatan Kerja, Medan: USU Press, 2008

Soeroso, R,Pengantar Ilmu Hukum. Jakarta: Sinar Grafika,2006.

Utami, Wahyu, Pengantar Hukum Bisnis, Jakarta : Jala Permata Aksara, Jakarta, 2017.

\section{Peraturan Perundang-Undangan}

Undang - Undang Nomor 1 Tahun 1970 tentang Keselamatan dan Kesehatan kerja.

Undang - Undang Nomor 13 Tahun 2003 tentang Ketenagakerjaan.

Undang - Undang Nomor 40 Tahun 2007 tentang Hukum Perusahaan.

Peraturan Pemerintah Nomor 50 Tahun 2012 tentang Penerapan Sistem Manajemen Keselamatan dan Kesehatan Kerja.

\section{Jurnal}

Christie Pricilia Pelealu, Jermias Tjakra, B.F.Sompie, "Penerapan Aspek Hukum Terhadap Keselamatan Dan Kesehatan Kerja ( Studi Ksus: Proyek The Lagoon Taman Sari Bahu Mall)", Jurnal Sipil Statik, Vol.3.No.5 Mei 2015 (331-340) ISSN.2337-6732.

Erni Darmayanti, "Perlindungan Hukum Terhadap Pelaksanaan Keselamatan Dan Kesehatan

Kerja (K3) Pada Perusahaan”, Jurnal Cendikia Hukum, Vol.3 No.2, (Maret 2018):286. 